\title{
Jurist-Diction
}

Volume 4 No. 5, September 2021

\section{Keabsahan Pembentukan Holding Badan Usaha Milik Negara Minyak dan Gas (BUMN MIGAS)}

\author{
Moch. Faizal Nauvaldy \\ mfnauvaldy.1312@yahoo.com \\ Universitas Airlangga
}

\begin{abstract}
How to cite:
Moch. Faizal Nauvaldy,

'Keabsahan Pembentukan

Holding Badan Usaha Milik

Negara Minyak dan Gas (BUMN MIGAS)

' (2021) Vol. 4 No. 5 Jurist-

Diction.
\end{abstract}

Histori artikel:

Submit 15 Juli 2021;

Diterima 15 Agustus 2021;

Diterbitkan 1 September 2021.

DOI:

10.20473/jd.v4i5.29821

p-ISSN: 2721-8392

e-ISSN: $2655-8297$

\section{Abstract}

A business entity is referred to as a state-owned enterprise due to the State's position as the majority shareholder and as the holder of control over such business entity. Various government efforts in terms of maintaining their position in State-Owned Enterprises (BUMN) are carried out through restructuring or by forming new concepts in the form of holding companies. The concept of holding companies is a new concept that has not yet been regulated in Indonesian positive law. One of them is the government's efforts in developing the business of StateOwned Enterprises (BUMN) in the oil and gas sector. In the formation of oil and gas BUMN holding, this is done through several methods or stages that follow the provisions of positive Indonesian law on limited liability companies. However, not only that, the establishment of the holding of the Oil and Gas State-Owned Enterprises also needs to be reviewed from several other arrangements relating to the fact that there is no specific provision governing the position or process of forming the holding itself.

Keywords: Holding; BUMN; Oil and Gas; Participation; Transfer; Transformation.

\section{Abstrak}

Suatu badan usaha disebut sebagai badan usaha milik negara disebabkan adanya kedudukan Negara sebagai pemegang saham mayoritas dan sebagai pemegang kendali atas suatu badan usaha tersebut. Berbagai usaha pemerintah dalam hal mempertahankan kedudukannya pada Badan Usaha Milik Negara (BUMN) dilakukan melalui bentuk restrukturisasi atau dengan membentuk konsep baru berupa holding company. Konsep holding company ini merupakan suatu konsep baru yang hingga saat ini belum terdapat pengaturannya dalam hukum positif Indonesia. Salah satunya yaitu usaha pemerintah dalam pengembangan bisnis Badan Usaha Milik Negara dalam sektor minyak dan gas. Dalam pembentukan holding BUMN Minyak dan Gas ini dilakukan melalui beberapa metode atau tahapan yang mengikuti ketentuan hukum positif Indonesia tentang Perseroan Terbatas. Namun, tidak hanya itu, pembentukan holding BUMN Minyak dan Gas ini juga perlu ditinjau dari beberapa pengaturan lain yang berkaitan dengan mengingat belum adanya ketentuan khusus yang mengatur kedudukan atau proses pembentukan holding itu sendiri.

Kata Kunci: Holding; BUMN; Migas; Penyertaan; Pengalihan; Transformasi. 


\section{Pendahuluan}

Kewenangan dalam pengawasan Badan Usaha Milik Negara berada dalam tangan pemerintah dalam hal ini Kementerian yang membawahi yaitu Kementerian Badan Usaha Milik Negara. Kementerian Badan Usaha Milik Negara selalu berusaha untuk mengembangkan potensi perusahaan yang digenggamnya, dalam hal ini Negara sebagai pemegang saham, dengan berbagai macam langkah. Pada 25 Januari 2016, Kementerian BUMN menerbitkan sebuah keputusan berupa Keputusan Menteri BUMN No. SK-16/MBU/01/2016 tentang Rencana Strategis Kementerian BUMN Tahun 2015-2019 yang pada pokoknya memuat untuk membuat BUMN lebih ramping dan gesit, dan tidak terbebani oleh hal-hal non profesional. ${ }^{1}$ Atas tindak lanjut keputusan tersebut, Kementerian BUMN mengadakan Rapat Terbatas Pembentukan Perusahaan Induk (Holding Company) BUMN pada 29 Februari 2016, dengan dilanjutkan pada Rapat Terbatas mengenai Lanjutan Pembahasan Holdingisasi BUMN yang memutuskan untuk penggabungan BUMN ini dimaksudkan untuk memperkuat peran BUMN dalam persaingan, terutama dalam persaingan global. Dari sinilah latar belakang dari diterbitkannya suatu kebijakan pemerintah mengenai pengaturan penyertaan modal negara pada BUMN yaitu Peraturan Pemerintah Nomor 72 Tahun 2016 tentang Perubahan Atas Peraturan Pemerintah Nomor 44 Tahun 2005 tentang Tata Cara Penyertaan dan Penatausahaan Modal Negara Pada Badan Usaha Milik Negara dan Perseroan Terbatas.

Atas adanya Keputusan Menteri BUMN No. SK-16/MBU/01/2016 tentang Rencana Strategis Kementerian BUMN Tahun 2015-2019, salah satu rencana strategis pemerintah yaitu membentuk suatu Holding dalam bidang minyak dan gas. Dalam lingkup holding Migas, oleh Kementerian Badan Usaha Milik Negara (BUMN) memutuskan untuk mengalihkan saham pemerintah sebesar 57,3\% yang berada di PGN ke Pertamina. Pengalihan saham ini merupakan langkah awal pembentukan holding BUMN Migas. ${ }^{2}$

\footnotetext{
${ }^{1}$ Keputusan Menteri BUMN No. SK-16/MBU/01/2016 tentang Rencana Strategis Kementerian BUMN Tahun 2015-2019.

2 Rivi Satrianegara, "Begini Tahap Pembentukan Holding BUMN Migas”, https://www.cnbcindonesia.com/news/20180123165622-4-2307/begini-tahap-pembentukan-holding-bumn-migas, 23 Januari 2018, dikunjungi pada tanggal 5 Desember 2019.
} 
Upaya awal yang dilakukan oleh pemerintah dalam pembentukan holding migas ini diawali dengan penyelenggaraan Rapat Umum Pemegang Saham Luar Biasa (RUPSLB) pada 25 Januari 2018 guna meminta persetujuan pemegang saham soal pengalihan 57,3\% saham pemerintah kepada Pertamina. Apabila disepakati, maka PGN resmi menjadi anak usaha Pertamina. PGN akan menjadi subholding gas, termasuk dengan Pertagas yang pada saat itu masih tercatat sebagai anak usaha Pertamina. Hasil dari langkah tersebut lalu, pemerintah mengeluarkan Peraturan Pemerintah Nomor 6 Tahun 2018 yang menetapkan terjadi penambahan modal pada kepemilikan negara atas saham dari PT Pertamina (Persero) yang berasal dari tindakan Pemerintah terkait dengan pengalihan seluruh saham seri B pada PT PGN ((Persero). Hal ini sebagai bentuk pemenuhan syarat Pasal 3 ayat (1) Peraturan Pemerintah Nomor 44 Tahun 2005 jo. Peraturan Pemerintah Nomor 72 Tahun 2016.

\section{Prosedur Pembentukan Holding Badan Usaha Milik Negara (BUMN) Minyak dan Gas (Migas)}

Prosedur pembentukan holding Migas ini dilatar belakangi dengan Keputusan Menteri BUMN No.SK: 16/MBU/01/2016 tentang Rencana Strategis Kementerian BUMN Tahun 2015 - 2016. Selanjutnya dilakukannya Rapat Umum Pemegang Saham Luar Biasa (RUPS-LB) PT Perusahaan Gas Negara (PGN) (Persero) terkait Perubahan Anggaran Dasar atau AD/ART pada 25 Januari 2018, sebagai arahan dari Kementerian BUMN. Dengan diterbitkannya kebijakan pemerintah melalui Peraturan Pemerintah Nomor 6 Tahun 2018 tentang Penambahan Penyertaan Modal Negara Republik Indonesia ke Dalam Modal Saham Perusahaan Perseroan (Persero) PT Pertamina pada 28 Februari 2018 dan Keputusan Menteri Keuangan No. 286/ KMK.06/2018 tentang Penetapan Nilai Penambahan Penyertaan Modal Negara Republik Indonesia ke Dalam Modal Saham Perusahaan Perseroan (Persero) PT Pertamina pada 28 Maret 2018.

Atas pengaturan tersebut maka pada 11 April2018, dilakukan Penandatanganan Akta Inbreng Saham antara Kementerian BUMN dan PT Pertamina (Persero) sebagai tindak lanjut Peraturan Pemerintah Nomor 6 Tahun 2018 dan Keputusan Menteri 
Keuangan (KMK) No. 286/KMK.06/2018. Dengan telah ditandatanganinya Akta Pengalihan Saham, seluruh aspek administratif legal holding migas telah selesai dan PGN resmi menjadi anak usaha Pertamina. Dengan dilanjutkan pembelian saham PT Pertamina (Persero) di PT Pertamina Gas (Pertagas) oleh PT Perusahaan Gas Negara (PGN) (Persero) pada 29 Juni 2018 dengan Penandatanganan Perjanjian Jual Beli Saham melalui CSPA yang memuat persetujuan atas cakupan dan nilai transaksi, PT Pertamina Gas (Pertagas) secara resmi terkonsolidasi ke PT Perusahaan Gas Negara (PGAS) (30 September 2018).

Akibatnya terjadinya pengalihan kepemilikan saham dan transformasi saham, adanya pengalihan kepemilikan saham (transformasi saham) berdasarkan pada Peraturan Pemerintah Nomor 6 Tahun 2018 tentang Penambahan Penyertaan Modal Negara Republik Indonesia ke Dalam Modal Saham Perusahaan Perseroan (Persero) PT Pertamina; Keputusan Menteri Keuangan No. 286/KMK.06/2018 tentang Penetapan Nilai Penambahan Penyertaan Modal Negara Republik Indonesia ke Dalam Modal Saham Perusahaan Perseroan (Persero) PT Pertamina; dan Akta Pernyataan Perjanjian Pengalihan Hak Atas Saham No. 30 antara Negara Republik Indonesia dan PT Pertamina (Persero) yang dibuat dihadapan Aulia Taufani, S.H., Notaris di Jakarta pada tanggal 13 April 2018.

Transformasi saham terjadi dimana saham seri B milik Pemerintah yang dialihkan tersebut menjadi tambahan penyertaan modal negara ke dalam modal saham PT Pertamina (Persero), sehingga saham milik negara yang telah dialihkan tersebut menjadi kekayaan dari PT Pertamina (Persero). Selanjutnya PT Pertamina (Persero) menerima tambahan modal saham adalah melakukan transformasi saham untuk menjadi penyertaan kedalam modal PT PGN (Persero) sejumlah 56,96\% saham. Dengan adanya proses transformasi saham tersebut PT Pertamina (Persero) menjadi pemilik saham mayoritas dari PT PGN (Persero) dan menggantikan posisi Negara dalam struktur permodalan pada PT PGN (Persero). ${ }^{3}$

\footnotetext{
${ }^{3}$ Risma Intan Fitriani, 'Akibat Hukum Tindakan Pemerintah dan Tindakan Perseroan Dalam Transformasi Saham Milik Pemerintah Pada Holdingisasi BUMN Persero’, Tesis (Program Pascasarjana Universitas Airlangga 2019).[21].
} 
Akibat selanjutnya yaitu terjadi perubahan susunan pemegang saham PT Perusahaan Gas Negara (Persero). Pembentukan holding Migas membuat perubahan struktur kepemilikan saham dalam PT Perusahaan Gas Negara, diantaranya menjadi:

a. Negara Republik Indonesia mempunyai 1 (satu) saham Seri A Dwiwarna;

b. PT Pertamina (Persero) mempunyai saham sebanyak 13.809.038.755 (tiga belas miliar delapan ratus sembilan juta tiga puluh delapan ribu tujuh ratus lima puluh lima) saham Seri B atau sebesar 56.96\%;

c. Masyarakat (Publik) mempunyai saham sebesar 10.432.469.440 (sepuluh miliar empat ratus tiga puluh dua juta empat ratus enam puluh sembilan ribu empat ratus empat puluh) saham Seri B atau sebesar 43,04\%.

Selanjutnya, terjadi perubahan status perseroan PT Perusahaan Gas Negara (PGN) (Persero). Kedudukan PT PGN (Persero) berubah sebagai peseroan terbatas berdasarkan Undang-Undang No. 40 Tahun 2007 tentang Perseroan Terbatas. Dimana perubahan pada status perseroan yang awalnya sebagai Badan Usaha Milik Negara Persero berubah menjadi non-persero, sehingga PT Perusahaan Gas Negara (PGAS). Perubahan ini seiring dengan pengalihan sebesar 13.809.038.755 (tiga belas miliar delapan ratus sembilan juta tiga puluh delapan ribu tujuh ratus lima puluh lima) saham Seri B milik pemerintah kepada PT Pertamina (Persero) berdasarkan ketiga dasar pengalihan kepemilikan saham, maka PT Pertamina (Persero) menjadi induk usaha holding.

Sehingga, PT Perusahaan Gas Negara (PGN) menjadi anak perusahaan BUMN. Kedudukan PT Perusahaan Gas Negara (PGAS) selain berubah dari BUMN Persero menjadi non persero, juga menjadi anak perusahaan BUMN. Dimana PT Pertamina (Persero) akan membawahi PT Perusahaan Gas Negara (PGAS) sebagai salah satu anak perusahaan yang akan berperan sebagai Sub Holding Gas (Gas Co) yang mengelola bisnis gas bumi terintegrasi. Dengan demikian perseroan berubah menjadi anak perusahaan BUMN sebagaimana dimaksud dalam Peraturan Pemerintah Nomor 72 Tahun 2016. Menurut Pasal 2A ayat (7) Peraturan Pemerintah ini menyatakan bahwa: 
Anak perusahaan BUMN sebagaimana dimaksud pada ayat (2) diperlakukan sama dengan BUMN untuk hal sebagai berikut:

a. mendapatkan penugasan Pemerintah atau melaksanakan pelayanan umum; dan/atau

b. mendapatkan kebijakan khusus negara dan/atau Pemerintah, termasuk dalam pengelolaan sumber daya alam dengan perlakuan tertentu sebagaimana diberlakukan bagi BUMN.

Sehingga kedudukan PT Perusahaan Gas Negara (PGAS) juga mendapatkan kebijakan khusus sebagaimana diberlakukan bagi BUMN, antara lain dalam proses dan bentuk perizinan, hak untuk memperoleh Hak Pengelolaan, kegiatan perluasan lahan dan/atau keikutsertaan dalam kegiatan-kegiatan kenegaraan atau pemerintahan yang melibatkan BUMN.

Selain itu, akibatnya terjadi Proses Integrasi PT Pertamina Gas (Pertagas) kedalam PT Perusahaan Gas Negara (PGAS). Proses integrasi ini sebagai satu rangkaian proses holding migas. Integrasi tahap awal, dilakukan antara PT Perusahaan Gas Negara (PGAS) dengan PT Pertamina Gas (Pertagas) untuk fokus memperkuat bisnis utama pada transmisi dan distribusi yang ditujukan untuk memberikan nilai tambah bagi penyaluran gas bumi dalam negeri.

Dalam pembentukan holding BUMN Migas ini, dilakukan dengan penyertaan modal negara adalah pemisahan kekayaan Negara dari Anggaran Pendapatan dan Belanja Negara atau penetapan cadangan perusahaan atau sumber lain untuk dijadikan sebagai modal BUMN dan/atau Perseroan Terbatas lainnya, dan dikelola secara korporasi. Hal ini sebagaimana ditegaskan dalam Pasal 1 angka 7 Peraturan Pemerintah Nomor 72 Tahun 2016 tentang Perubahan Atas Peraturan Pemerintah Nomor 44 Tahun 2005 tentang Tata Cara Penyertaan dan Penatausahaan Modal Negara Pada Badan Usaha Milik Negara dan Perseroan Terbatas. Sumber Penyertaan Modal Negara pada BUMN tersebut berasal dari Anggaran Pendapatan dan Belanja Negara, kapitalisasi cadangan, dan/atau sumber lainnya. Sumber penyertaan modal negara yang berasal dari Anggaran dan Pendapatan Belanja Negara berupa dana segar, proyek- proyek yang dibiayai dari Anggaran Pendapatan dan Belanja Negara, piutang negara pada BUMN atau Perseroan Terbatas serta aset-aset negara lainnya 
berupa keuntungan revaluasi aset dan/atau agio saham. ${ }^{4}$

Sumber penyertaan modal negara kedalam BUMN ini telah ditegaskan dalam Pasal 2 ayat (1) Peraturan Pemerintah Nomor 72 Tahun 2016 tentang Perubahan Atas Peraturan Pemerintah Nomor 44 Tahun 2005 tentang Tata Cara Penyertaan dan Penatausahaan Modal Negara Pada Badan Usaha Milik Negara dan Perseroan Terbatas. Melalui sumber yang berasal dari Anggaran Pendapatan dan Belanja Negara, pemerintah mengklasifikasikan menjadi beberapa sumber yang spesifik yang meliputi kekayaan negara, sebagaimana disebutkan dalam Pasal 2 ayat (2) Peraturan Pemerintah tersebut. Sumber Penyertaan Modal Negara yang berasal dari Anggaran Pendapatan dan Belanja Negara sebagaimana dimaksud pada ayat (1) huruf a meliputi kekayaan negara berupa:

a. dana segar;

b. barang milik negara;

c. piutang negara pada BUMN atau Perseroan Terbatas;

d. saham milik negara pada BUMN atau Perseroan Terbatas; dan/ atau

e. aset negara lainnya.

Sumber penyertaan modal negara dalam holding migas ini adalah saham milik negara pada BUMN atau Perseroan Terbatas. Saham milik negara tersebut awalnya berasal atau terdapat pada PT Perusahaan Gas Negara (PGAS) yaitu sebesar 56,86\% sebagai 1 saham dwiwarna. Yang kemudian atas adanya pembentukan holding ini, pemerintah melakukan penyertaan modal negara kepada PT Pertamina (Persero) melalui saham negara yang terdapat pada PT Perusahaan Gas Negara (PGAS) tersebut. Sehingga, terjadi pengalihan saham berupa penyertaan modal negara kepada PT Pertamina (Persero) yang mengakibatkan terjadinya transformasi saham.

Sumber penyertaan modal negara dalam proses ini termasuk dalam salah satu jenis sumber penyertaan modal negara sebagaimana dimaksud dalam Pasal 2 ayat (2) huruf d Peraturan Pemerintah Nomor 72 Tahun 2016 tentang Perubahan Atas Peraturan Pemerintah Nomor 44 Tahun 2005 tentang Tata Cara Penyertaan

${ }^{4}$ David Putra Timbo, Peter Mahmud Marzuki, 'Status Uang APBN Yang Dipisahkan Dan Dijadikan Penyertaan Modal Pada Bumn Persero', (Magister Ilmu Hukum UNDIP, Semarang) https:// media.neliti.com/media/publications/109556-ID-status-uang-apbn-yang-dipisahkan-dan-dij.pdf dikunjungi pada tanggal 11 Desember 2019.[7]. 
dan Penatausahaan Modal Negara Pada Badan Usaha Milik Negara dan Perseroan Terbatas. Namun, menurut Pasal 2A ayat (1), dikatakan bahwa penyertaan modal negara yang dimaksud dalam Pasal 2 ayat (2) huruf d ini dilakukan oleh Pemerintah Pusat tanpa melalui Anggaran Pendapatan dan Belanja Negara (APBN).

\section{Pengalihan Hak Atas Saham Sebagai Akibat Dari Penyertaan Modal Negara Yang Bersumber Pada Saham Milik Negara Pada BUMN}

Penyertaan modal negara sebagai akuisisi saham Negara menurut Peraturan Pemerintah Nomor 43 Tahun 2005 tentang Penggabungan, Peleburan, Pengambilalihan, dan Perubahan Bentuk Badan Hukum Badan Usaha Milik Negara, pada dasarnya, mengenai akuisisi yang dilakukan oleh BUMN, telah diatur dalam Peraturan Pemerintah No. 43 Tahun 2005 tentang Penggabungan, Peleburan, Pengambilalihan dan Perubahan Bentuk Badan Hukum BUMN. Dalam Peraturan Pemerintah ini, pengaturan lebih rinci dilakukan terhadap proses Penggabungan, Peleburan, dan Pengambilalihan yang terkait dengan Perum. Walaupun demikian, proses Penggabungan, Peleburan dan Pengambilalihan Perum yang diatur dalam Peraturan Pemerintah ini mengacu pada prinsip-prinsip yang berlaku bagi Penggabungan, Peleburan dan Pengambilalihan perseroan terbatas.

Dimana suatu pengambilalihan yang dinyatakan dalam Pasal 1 angka 6 Peraturan Pemerintah ini menegaskan bagi subjek yang melakukan perbuatan hukum ini, sebagaimana bahwa pengambilalihan adalah perbuatan hukum yang dilakukan oleh BUMN untuk mengambil alih baik sebagian besar maupun seluruh saham BUMN atau perseroan terbatas yang dapat mengakibatkan beralihnya pengendalian terhadap BUMN atau perseroan terbatas tersebut. Pada dasarnya pengertian yang dinyatakan tersebut sama halnya dengan pengertian yang ditegaskan dalam Peraturan Pemerintah Nomor 27 Tahun 1998, namun dalam pengaturan ini lebih ditegaskan bahwa perbuatan hukum tersebut dilakukan oleh suatu Badan Usaha Milik Negara (BUMN), sebagai badan usaha yang seluruh atau sebagian besar modalnya dimiliki oleh negara melalui penyertaan langsung yang berasal dari kekayaan negara yang dipisahkan (Pasal 1 angka 1 Undang-Undang Nomor 19 Tahun 2003 tentang Badan Usaha Milik Negara). 
Tata cara pengambilalihan yang dilakukan BUMN yaitu berdasarkan Pasal 9 Peraturan Pemerintah No. 43 Tahun 2005 tentang Penggabungan, Peleburan, Pengambilalihan, dan Perubahan Bentuk Badan Hukum Badan Usaha Milik Negara.

Penyertaan modal negara sebagai akuisisi saham Negara menurut Peraturan Pemerintah Nomor 44 Tahun 2005 juncto Peraturan Pemerintah Nomor 72 Tahun 2016 tentang Tata Cara Penyertaan Dan Penatausahaan Modal Negara Pada Badan Usaha Milik Negara dan Perseroan Terbatas, untuk mewujudkan kesejahteraan umum melalui badan usaha, maka Pemerintah melakukan Penyertaan Modal Negara untuk mendirikan Badan Usaha Milik Negara. Selanjutnya untuk menyelamatkan perekonomian nasional, Pemerintah dapat pula melakukan Penyertaan Modal Negara ke dalam Perseroan Terbatas yang di dalamnya belum terdapat saham milik negara. Penyertaan Modal Negara seperti ini dilakukan oleh Pemerintah dengan mengeluarkan dana dari Anggaran Pendapatan dan Belanja Negara (APBN).

Salah satu strategi Pemerintah dalam pembentukan perusahaan induk BUMN yaitu dengan melakukan Penyertaan Modal Negara yang bersumber dari pergeseran saham milik negara pada BUMN dan/atau Perseroan Terbatas tertentu kepada BUMN dan/atau Perseroan Terbatas lainnya.

Menurut Pasal 1 angka 7 Peraturan Pemerintah Nomor 72 Tahun 2016, mengatur maksud dari penyertaan modal negara yaitu Penyertaan Modal Negara adalah pemisahan kekayaan Negara dari Anggaran Pendapatan dan Belanja Negara atau penetapan cadangan perusahaan atau sumber lain untuk dijadikan sebagai modal BUMN dan/atau Perseroan Terbatas lainnya, dan dikelola secara korporasi.

Adapun bentuk sumber penyertaan modal negara dalam suatu Badan Usaha Milik Negara dan Perseroan Terbatas untuk dijadikan sebagai modal, terdapat dalam beberapa bentuk, sebagaimana dijabarkan dalam Pasal 2 Peraturan Pemerintah Nomor 72 Tahun 2016.

Pasal 2

(1)Penyertaan Modal Negara ke dalam BUMN dan Perseroan Terbatas bersumber dari:

a. Anggaran Pendapatan dan Belanja Negara;

b. kapitalisasi cadangan; dan/atau 
1844 Moch. Faizal: Keabsahan Pembentukan Holding...

c. sumber lainnya.

(2)Sumber Penyertaan Modal Negara yang berasal dari Anggaran Pendapatan dan Belanja Negara sebagaimana dimaksud pada ayat (1) huruf a meliputi kekayaan negara berupa:

a. dana segar;

b. barang milik negara;

c. piutang negara pada BUMN atau Perseroan Terbatas;

d. saham milik negara pada BUMN atau Perseroan Terbatas; dan/ atau

e. aset negara lainnya.

(3)Sumber Penyertaan Modal Negara yang berasal dari sumber lainnya sebagaimana dimaksud pada ayat (1) huruf c meliputi:

a. keuntungan revaluasi aset; dan/atau

b. agio saham

Berdasarkan ketentuan tersebut disebutkan bahwa penyertaan modal negara, saham milik negara pada BUMN atau Perseroan Terbatas pada hakikatnya merupakan kekayaan negara yang sudah dipisahkan dari Anggaran Pendapatan dan Belanja Negara, sehingga pengalihan saham dimaksud untuk dijadikan penyertaan pada BUMN atau Perseroan Terbatas tidak dilakukan melalui mekanisme Anggaran Pendapatan dan Belanja Negara. Pada Pasal 2A ayat (1) Peraturan Pemerintah ini melanjutkan bahwa (1) penyertaan modal Negara yang berasal dari kekayaan negara berupa saham milik negara pada BUMN atau Perseroan Terbatas sebagaimana dimaksud dalam Pasal 2 ayat (2) huruf d kepada BUMN atau Perseroan Terbatas lain, dilakukan oleh Pemerintah Pusat tanpa melalui mekanisme Anggaran Pendapatan dan Belanja Negara.

Akibat penyertaan modal negara terhadap BUMN pada Holding BUMN Migas, bahwa pembentukan Holding Migas ini berasal dari adanya transformasi saham kepada PT Pertamina (Persero). Struktur kepemilikan saham sebelum pembentukan holding migas ini, keberadaan 56,96\% merupakan saham milik Negara (1 saham Dwiwarna) terhadap PT Perusahaan Gas Negara (Persero). Namun, dengan adanya pembentukan Holding Migas ini, maka ada perubahan atas kepemilikan saham 56,96\% tersebut. Setelah pembentukan Holding Migas ini, kedudukan 56,96\% saham Negara dialihkan sebagai penyertaan modal Negara dalam pembentukan Holding ini. Dimana peralihan ini merupakan bagian dari klasifikasi sumber penyertaan modal Negara sebagaimana dalam Pasal ayat (2) huruf d, yaitu sumber 
penyertaan modal Negara yang berasal dari Anggaran Pendapatan dan Belanja Negara meliputi kekayaan negara berupa saham milik negara pada BUMN atau Perseroan Terbatas.

Mengenai akibat dari adanya penyertaan modal Negara terhadap BUMN berupa saham milik negara pada BUMN, telah diatur dalam Pasal 2 ayat (2) Peraturan Pemerintah Nomor 72 Tahun 2016, dimana ${ }^{5}$ dalam hal kekayaan negara berupa saham milik negara pada BUMN sebagaimana dimaksud dalam Pasal 2 ayat (2) huruf d dijadikan penyertaan modal negara pada BUMN lain sehingga sebagian besar saham dimiliki oleh BUMN lain, maka BUMN tersebut menjadi anak perusahaan BUMN dengan ketentuan negara wajib memiliki saham dengan hak istimewa yang diatur dalam anggaran dasar.

Dengan adanya Induk perusahaan, maka secara langsung Induk perusahaan bertanggung jawab atas segala tindakan hukum yang dilakukan oleh anak perusahaan. Ini dapat diartikan bahwa, kewajiban anak perusahaan juga merupakan kewajiban dari Induk perusahaan dalam sebuah Holding Company. Hal yang mendasari pernyataan tersebut adalah: ${ }^{6}$

a. Keuntungan dari anak perusahaan juga merupakan keuntungan dari Perusahaan induk atau Holding (serpeti melalui bagi hasil,dll);

b. Sumber daya manusia menejerial dari anak perusahaan dibentuk serta dipilih oleh Induk perusahaan;

c. Induk perusahaan merupakan "kepala dan jiwa" dari anak perusahaan (seperti dalam mengambil keputusan strategis, anak perusahaan harus mendapatkan persetujuan dari Induk perusahaan);

d. Perusahaan Induk mengatur semua kebijakan anak perusahaan dalam kaitannya mengatur cash flow secara makro (seperti penambahan aset, pembayaran pada supplier utama, penanaman modal, dll.);

e. Induk Perusahaan mendapatkan keuntungan sendiri melalui cara-cara strategis yang dilakukan melalui anak perusahaan;

f. Perusahaan induk secara aktif dan konstan mengontrol semua lini anak perusahaan.

${ }^{5}$ Pasal 2A ayat (2) Peraturan Pemerintah Nomor 72 Tahun 2016.

${ }^{6}$ Adhi Suryo Judhanto, 'Pembentukan Holding Company BUMN Dalam Perspektif Hukum Persaingan Usaha’ (2018) Vol. IV No. 2 E-Jurnal Spirit Pro Patria.[166]. 
Pada dasarnya, Pemerintah mengalihkan kepemilikan saham 56,96\% di PGN ke Pertamina. Secara administratif, status Persero PGN menjadi hilang. Setelah dijadikan penyertaan modal negara pada BUMN atau Perseroan terbatas, maka kekayaan negara tersebut bertransformasi menjadi saham/modal BUMN atau Perseroan Terbatas yang bersangkutan yang dimiliki oleh Negara, sehingga status kekayaan negara berubah dari kekayaan negara tidak dipisahkan menjadi modal/ saham yang merupakan kekayaan negara dipisahkan. Dengan demikian, walaupun kekayaan negara tersebut berubah menjadi kekayaan BUMN atau Perseroan Terbatas akibat transformasi tersebut, namun masih memiliki hubungan dengan negara dengan status negara sebagai pemegang saham atau pemilik modal. Dilanjutkan dalam Pasal 2 ayat (4) bahwa kekayaan negara yang telah bertransformasi tersebut akan menjadi bentuk kekayaan BUMN atau Perseroan Terbatas tersebut.

Seperti yang dinyatakan dalam Pasal 2A ayat (2) tersebut, bahwa BUMN tersebut akan menjadi anak perusahaan BUMN. Komposisi anak perusahaan BUMN tersebut dimiliki sebagian besar sahamnya tetap dimiliki BUMN lain tersebut. Kepemilikan BUMN induk tetap memiliki lebih dari 50\% saham (mayoritas) pada perusahaan anak eks BUMN. Hal ini dimaksudkan agar negara tetap dapat melakukan kontrol melalui BUMN Induk serta terkait pula dengan perlakukan disamakan dengan BUMN. Kedudukan anak perusahaan diakui dalam Pasal 2 ayat (7) yang mana akan diperlakukan sama dengan BUMN.

\section{Transformasi Saham Sebagai Akibat Dari Pengalihan Hak Atas Saham}

Akibat dari adanya pengalihan hak atas saham tersebut, mengakibatkan terjadinya transformasi saham yang merupakan akibat dari pengalihan hak atas saham pada seluruh saham Seri B milik pemerintah yang terdapat pada PT Perusahaan Gas Negara (Persero) Tbk sebesar 56,96\% sebanyak 13.809.038.755 saham Seri B. Pengalihan saham ini selanjutnya digunakan sebagai tambahan penyertaan modal negara ke PT Pertamina (Persero).

Proses selanjutnya setelah PT Pertamina (Persero) menerima tambahan modal saham adalah melakukan transformasi saham untuk menjadi penyertaan 
kedalam modal PT PGN (Persero) sejumlah 56,96\% saham. Dengan adanya proses transformasi saham tersebut PT Pertamina (Persero) menjadi pemilik saham mayoritas dari PT PGN (Persero) dan menggantikan posisi Negara dalam struktur permodalan pada PT PGN (Persero). ${ }^{7}$ Maka dalam hal ini terjadinya transformasi saham bermula dari pengalihan hak atas saham ini.

Atas pengalihan hak atas saham sebagai kekayaan negara sebagaimana dimaksud yang dijadikan penyertaan modal negara pada BUMN atau Perseroan Terbatas, bertransformasi menjadi saham/modal negara pada BUMN atau Perseroan Terbatas tersebut, dan menjadi kekayaan BUMN atau Perseroan Terbatas tersebut. Menurut Penjelasan Pasal 2A ayat (3) PP Nomor 72 Tahun 2016, dinyatakan bahwa Setelah dijadikan penyertaan modal negara pada BUMN atau Perseroan Terbatas, maka kekayaan negara tersebut bertransformasi menjadi saham/modal BUMN atau Perseroan Terbatas yang bersangkutan yang dimiliki oleh negara, sehingga status kekayaan negara berubah dari kekayaan negara tidak dipisahkan menjadi modal atau saham yang merupakan kekayaan .negara dipisahkan. Dengan demikian, walaupun kekayaan negara tersebut berubah menjadi kekayaan BUMN atau Perseroan Terbatas akibat transformasi tersebut, namun masih memiliki hubungan dengan negara karena status negara sebagai pemegang saham/pemilik modal. ${ }^{8}$

\section{Pengalihan Hak Atas Saham Dari PT Perusahaan Gas Negara (PGN) (Persero) Ke PT Pertamina (Persero) Dalam Perspektif Peraturan Perundang-Undangan}

Parameter keabsahan hukum atas suatu perbuatan atau tindakan hukum seperti pengambilalihan saham ini dapat dilihat dari pemenuhan persyaratan atau legalitas dari ketentuan yang telah diatur dalam peraturan perundang-undangan terkait. Mengikuti yang diatur dalam Peraturan Pemerintah Republik Indonesia No. 27 Tahun 1998 tentang Penggabungan, Peleburan dan Pengambilalihan Perseroan Terbatas jo. Peraturan Pemerintah Nomor 44 Tahun 2005 jo. Peraturan Pemerintah Nomor 72 Tahun 2016 tentang Tata Cara Penyertaan

\footnotetext{
${ }^{7}$ Risma Intan Fitriani, Op.Cit.[21].

${ }^{8}$ Penjelasan Pasal 2A ayat (3) PP Nomor 72 Tahun 2016.
} 
dan Penatausahaan Modal Negara Pada BUMN dan Perseroan Terbatas, bahwa peraturan tersebut telah mengatur dalam Pasal 4 mengenai syarat- syarat yang harus dipenuhi dalam akan melakukan suatu perbuatan hukum pengambilalihan perusahaan, antara lain:

1) Penggabungan, peleburan, dan pengambilalihan hanya dapat dilakukan dengan memperhatikan:

a. kepentingan perseroan, pemegang saham minoritas, dan karyawan perseroan yang bersangkutan;

b. kepentingan masyarakat dan persaingan sehat dalam melakukan usaha.

2) Penggabungan, peleburan, dan pengambilalihan tidak mengurangi hak pemegang saham minoritas untuk menjual sahamnya dengan harga yang wajar.

3) Pemegang saham yang tidak setuju terhadap keputusan Rapat Umum Pemegang Saham mengenai penggabungan, peleburan, dan pengambilalihan hanya dapat menggunakan haknya agar saham yang dimilikinya dibeli dengan harga yang wajar sesuai dengan ketentuan Pasal 55 Undang-undang Nomor 1 Tahun 1995 tentang Perseroan Terbatas.

4) Pelaksanaan hak sebagaimana dimaksud dalam ayat (3) tidak menghentikan proses pelaksanaan penggabungan, peleburan, dan pengambilalihan.

Berdasarkan ketentuan tersebut kaitannya dengan pembentukan Holding BUMN Migas ini, bahwa pembentukan holding ini telah sesuai dengan latar belakangnya yang memperhatikan kepentingan pada pihak persero (internal) dan kepentingan masyarakat (pemegang saham publik) dan persaingan usaha. Dimana pembentukan holding migas ini guna menciptakan pula nilai tambah bagi pemegang saham dan karyawan antar perusahaan. Selain itu, menurut ketentuan pada ayat (2) tersebut dinyatakan bahwa untuk memperhatikan kepentingan pemegang saham minoritas.

Keabsahan pengalihan hak atas saham dalam pembentukan Holding BUMN Migas menurut Undang-Undang Nomor 19 Tahun 2003 tentang Badan Usaha Milik Negara, pelaksanaan pengambilalihan yang dilakukan oleh BUMN ini telah diatur dalam Pasal 63 Undang-Undang BUMN. Menurut Pasal 63 ayat (2), menyatakan bahwa suatu BUMN dapat mengambil alih BUMN dan/atau perseroan terbatas lainnya. ${ }^{9}$ Sehingga berdasarkan ketentuan ini, peraturan ini telah membolehkan 
apabila suatu BUMN ingin melakukan pengambilalihan dengan perseroan terbatas lainnya. Perbuatan hukum yang dilakukan oleh BUMN untuk mengambil alih BUMN lainnya atau Perseroan Terbatas, baik seluruh atau sebagian besar saham/ modal yang dapat mengakibatkan beralihnya pengendalian terhadap BUMN atau Perseroan Terbatas tersebut.

Berdasarkan Pasal 65 ayat (1) Undang-Undang BUMN, dinyatakan bahwa Ketentuan lebih lanjut mengenai penggabungan, peleburan, pengambilalihan, dan pembubaran BUMN, diatur dengan Peraturan Pemerintah. Karena setiap pendirian BUMN dilakukan dengan Peraturan Pemerintah, apabila ada perubahan terhadap keberadaan BUMN dimaksud, baik karena penggabungan, peleburan, pengambilalihan maupun pembubaran, harus dilakukan pula dengan Peraturan Pemerintah.

Prosedural pengalihan hak atas saham yang dikategorikan sebagai perbuatan hukum pengambilalihan diatur dalam Pasal 26 Peraturan Pemerintah Republik Indonesia No. 27 Tahun 1998 tentang Penggabungan, Peleburan dan Pengambilalihan Perseroan Terbatas, sebagai penjabaran Pasal 103 UndangUndang No. 40 Tahun 2007. Dimana pengalihan hak atas saham yang dilakukan oleh PT Pertamina (Persero) dan PT PGN (Persero) ini didahului dengan Rapat Umum Pemegang Saham Luar Biasa (RUPSLB) yang dilakukan pada tanggal 28 Januari 2018. Maka hal ini memenuhi ketentuan dalam tahap rencana akuisisi (yang diusulkan oleh Kementerian BUMN) yang disetujui dalam RUPS, hal ini berkaitan dengan Undang-Undang Perseroan Terbatas, pada Pasal 102, mengenai adanya persetujuan RUPS dalam melakukan pengalihan atau penjualan atas aset perseroan yang melebihi 50\% (lima puluh persen) dari kekayaan bersih perseroan dalam 1 (satu) transaksi.

Setelah dilakukan RUPS telah menyetujui atas rancangan pengalihan hak atas saham perseroan, maka rancangan akuisisi tersebut harus dituangkan dalam Akta Pengambilalihan yang sifatnya notariil. Akta notariil ini merupakan syarat mutlak (solemnitas causa), dengan ancaman batal. Maksudnya apabila akta 
pengambilalihan tersebut tidak dituangkan dengan akta autentik melalui notaris, ${ }^{10}$ maka pengambilalihan tersebut menjadi batal demi hukum. ${ }^{11}$ Hal ini dinyatakan dalam Pasal 31 Peraturan Pemerintah No. 27 Tahun 1998. Dalam proses pengalihan hak atas saham ini, setelah diterbitkannya Peraturan Pemerintah Holding BUMN Migas yang diikuti dengan penandatanganan Akta Inbreng oleh Pemerintah dan Pertamina, maka Pertamina menjadi pemegang saham seri B perseroan menggantikan posisi Negara. Namun demikian, Negara tetap dapat mengendalikan Perseroan melalui saham Seri A Dwiwarna yang mempunyai hak-hak istimewa.

Keabsahan pengalihan hak atas saham dalam pembentukan Holding BUMN Migas menurut Peraturan Pemerintah Nomor 44 Tahun 2005 jo. Peraturan Pemerintah Nomor 72 Tahun 2016 tentang Tata Cara Penyertaan dan Penatausahaan Modal Negara Pada BUMN dan Perseroan Terbatas, Holding dibentuk dengan mengalihkan saham milik negara yang ada pada PT PGN (Persero) Tbk untuk dijadikan tambahan penyertaan modal negara pada PT Pertamina (Persero). Sesuai dengan ketentuan pada Pasal 2 ayat (2) PP Nomor 72 Tahun 2016 yang menyebutkan bahwa sumber penyertaan modal negara yang berasal dari Anggaran Pendapatan Belanja Negara (APBN) meliputi kekayaan negara yang berupa dana segar, barang milik negara, piutang negara yang ada pada suatu BUMN Persero atau Perseroan Terbatas biasa, saham milik negara yang telah ada pada BUMN Persero atau Perseroan Terbatas lain dan atau aset negara lainnya. ${ }^{12}$

Dengan pembentukan Holding Migas ini berasal dari adanya transformasi saham kepada PT Pertamina (Persero), maka terjadi perubahan struktur kepemilikan saham sebelum pembentukan holding migas ini, keberadaan 56,96\% merupakan saham milik Negara (1 saham Dwiwarna) terhadap PT Perusahaan Gas Negara (PGN) (Persero). Namun, dengan adanya pembentukan Holding Migas ini, maka ada perubahan atas kepemilikan saham 56,96\% tersebut. Setelah pembentukan

\footnotetext{
${ }^{10}$ Menurut Pasal 1 ayat (1) jo. Pasal 15 ayat (1) Undang- Undang No. 2 Tahun 2014 tentang Jabatan Notaris, menyatakan bahwa Notaris adalah pejabat yang berwenang untuk membuat akta otentik.

${ }^{11}$ Munir Fuady, Hukum Perusahaan (Dalam Paradigma Hukum Bisnis) (Citra Aditya Bakti 2000).[23].

${ }^{12}$ Risma Intan Fitriani, Op.Cit.[20].
} 
Holding Migas ini, kedudukan 56,96\% saham Negara dialihkan sebagai penyertaan modal Negara dalam pembentukan Holding ini. Dimana peralihan ini merupakan bagian dari klasifikasi sumber penyertaan modal Negara sebagaimana dalam Pasal ayat (2) huruf d, yaitu sumber penyertaan modal Negara yang berasal dari Anggaran Pendapatan dan Belanja Negara meliputi kekayaan negara berupa saham milik negara pada BUMN atau Perseroan Terbatas. Sehingga dalam pembentukan holding ini telah sesuai dengan syarat yang diatur dalam ketentuan ini, dimana salah satu sumber penyertaan modal yang digunakan berupa saham milik negara pada BUMN atau perseroan terbatas. Yang mana dalam hal ini dalam pembentukan holding ini digunakan mekanisme transformasi saham.

\section{Kesimpulan}

Dalam Pembentukan Holding BUMN Migas pemerintah melakukan penyertaan modal yang bersumber pada saham milik negara pada BUMN, konsekuensinya Negara harus melakukan Pengalihan saham, dalam hal ini saham milik negara pada PT PGN (Persero) dialihkan ke PT Pertamina (Persero).

Pengalihan hak atas saham milik negara pada PT PGN (Persero) ke PT Pertamina (Persero) adalah sah karena telah memenuhi persyaratan yang diatur dalam peraturan perundang-undangan terkait. Pengalihan hak atas saham tersebut mengakibatkan terjadinya transformasi saham, sehingga terdapat perubahan atas kepemilikan saham milik negara sebesar 56,96\%. Setelah pembentukan Holding Migas ini, kedudukan 56,96\% saham Negara dialihkan sebagai penyertaan modal Negara dalam pembentukan Holding Migas.

\section{Daftar Bacaan}

\section{Buku}

Munir Fuady, Hukum Perusahaan (Dalam Paradigma Hukum Bisnis) (Citra Aditya Bakti 2000).

\section{Jurnal atau Makalah}

Arum Ambarwati, Analisis Perbedaan Kinerja Keuangan Sebelum Dan Sesudah Merger 
Dan Akuisisi Pada Perusahaan Non Keuangan Yang Terdaftar di BEI Tahun 20062012 (2012) Jurnal FEB Universitas Dian Nuswantoro Semarang, Semarang.

Adhi Suryo Judhanto, 'Pembentukan Holding Company BUMN Dalam Perspektif Hukum Persaingan Usaha’ (2018) Vol. IV No. 2 E-Jurnal Spirit Pro Patria.

David Putra Timbo, Peter Mahmud Marzuki, 'Status Uang APBN Yang Dipisahkan Dan Dijadikan Penyertaan Modal Pada Bumn Persero',(Magister Ilmu Hukum UNDIP, Semarang) https://media.neliti.com/media/publications/109556-IDstatus-uang-apbn-yang-dipisahkan-dan-dij.pdf dikunjungi pada tanggal 11 Desember 2019.

\section{Skripsi atau Tesis}

Risma Intan Fitriani, 'Akibat Hukum Tindakan Pemerintah dan Tindakan Perseroan Dalam Transformasi Saham Milik Pemerintah Pada Holdingisasi BUMN Persero', Tesis (2019) Program Pascasarjana Universitas Airlangga, Surabaya.

\section{Laman}

Rahadian, Aristya, 'Akuisisi Pertagas, Begini Struktur Organisasi Baru PGN', CNBC Indonesia, 3 Juli 2018, dikutip dari https:/www.cnbcindonesia. com/market/20180703114218-20-21606/akuisisi-pertagas-begini-strukturorganisasi-baru-pgn pada 19 Februari 2019.

Satrianegara, Rivi, 'Begini Tahap Pembentukan Holding BUMN Migas' https:// www.cnbcindonesia.com/news/20180123165622-4-2307/begini-tahappembentukan-holding-bumn-migas, 23 Januari 2018, dikunjungi pada tanggal 5 Desember 2019.

\section{Perundang-undangan}

Undang-Undang Nomor 19 Tahun 2003 tentang Badan Usaha Milik Negara, Lembaran Negara Republik Indonesia Tahun 2003 Nomor 70, Tambahan Lembaran Negara Republik Indonesia Nomor 4297.

Peraturan Pemerintah Nomor 72 Tahun 2016 tentang Perubahan Atas Peraturan Pemerintah Nomor 44 Tahun 2005 Tentang Tata Cara Penyertaan Dan Penatausahaan Modal Negara Pada Badan Usaha Milik Negara Dan Perseroan Terbatas, Lembaran Negara Republik Indonesia Tahun 2016 Nomor 325, Tambai-Ian Lembaran Negara Republik Indonesia Nomor 6006.

Keputusan Menteri BUMN No. SK-16/MBU/01/2016 tentang Rencana Strategis Kementerian BUMN Tahun 2015-2019. 